\title{
ANALYSIS OF INTRA-INDUSTRY TRADE IN COSMETIC COMMODITIES BETWEEN INDONESIA AND NINE TRADING PARTNERS IN THE ASIAN REGION IN THE PERIOD OF 2004-2018
}

\section{ANALYSIS OF INTRA-INDUSTRY TRADE IN COSMETIC COMMODITIES BETWEEN INDONESIA AND NINE TRADING PARTNERS IN THE ASIAN REGION IN THE PERIOD OF 2004-2018}

\author{
Tuhfah Ikbar Ramadhan'), Firmansyah'²* \\ ${ }^{1,2}$ Faculty of Economics and Business, Diponegoro University, Indonesia
}

\begin{abstract}
This research aims to analyze the level of intra-industry trade and the effect of average country size, average per capita income, difference in per capita income, distance, and average tariff on intra-industry trade of cosmetic commodities between Indonesia and nine trading partners (Singapore, Malaysia, Thailand, Philippines, India, China, Hong Kong, Japan, and South Korea) from 2004-2018. This study uses a Grubel-Llyod Index to determine the level of intra-industry trade and static panel data method to see the effect of independent variables on the level of intra-industry trade. The result shows that the level of intra-industry trade of cosmetic commodities between Indonesia and its trading partners (except India) still tended to be low. The average country size, average per capita income, and average tariff have a positive and significant effect on the level of intra-industry trade. Meanwhile, the difference in per capita income and distance have a negative and significant effect.
\end{abstract}

Keywords: Intra-Industry Trade, Grubel-Llyod Index, Cosmetic Commodities.

JEL Classification: F10, F12

\section{INTRODUCTION}

Throughout history, the theory of international trade has continued to experience change and development. As for the concept of international trade in terms of traditional thinking, international trade occurs if each country possesses and utilizes the difference of factor endowments. Each country will specialize in producing commodity that has a comparative advantage and then will import other commodity that also has a comparative advantage from other country (Halwani, 2002).

Nevertheless, many studies have stated that international trade is not enough if only explained by the theory of international trade which was based on comparative advantage. This is because the pattern of trade that occurs today is characterized by the dominance of trade between countries that generally have the similar factor endowments and also characterized by the exchange of similar goods, especially

\footnotetext{
*Corresponding author. Email address: firmansyah@live.undip.ac.id
} 


\section{AFEBI Economic and Finance Review (AEFR)}

\section{Volume 5, No 02 (2020)}

among developed countries (Krugman, 1981; Basri, 1992), Therefore, a new trade theory emerged that referred to as intra-industry trade which is considered as the answer to the new reality in the current pattern of international trade (Bato, 2014). In contrast to inter-industry trade, the intra-industry trade occurs when countries trade goods from the same industry. Intra-industry trade is mainly based on economies of scale and product differentiation.

Historically, cosmetics have been used by women and men to enhance their beauty, gain self-confidence, soften their skin, or even protect their health (Ramli, 2015). Nowadays in Indonesia, cosmetic products have become a part of society's lifestyle. Many people began to care about their appearance and cleanliness which was caused partly by the increased awareness of their cleanliness, cultural influences, or even because of their income level. According to The Ministry of Industry or KEMENPERIN (2018), currently, the domestic cosmetic industry has reached more than 760 firms, even in 2017 the number increased by 153 firms. The national cosmetic industry also experienced a fairly high growth to reach more than 20 percent in 2017. This is partly due to the high demand from the domestic and export market in line with the trend of people who considered beauty products and body care products as their primary needs.

Figure 1

The Dynamics of Indonesia's Cosmetics Export and Import Value in the Period of 2004-2018 (thousand US\$)

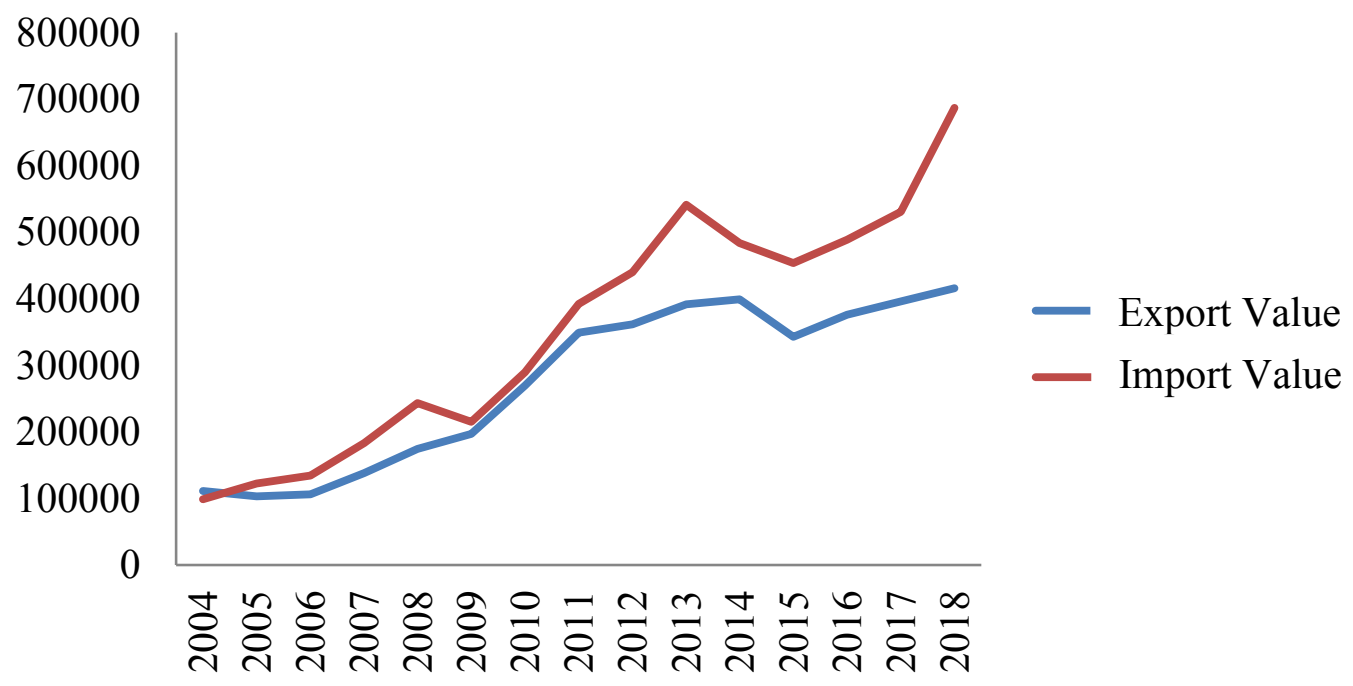

Source: International Trade Centre, processed (2019)

Figure 1 shows the value of export and import of Indonesia's cosmetic commodities which consist of HS 3303, HS 3304, HS 3305, HS 3306 and HS 3307. Based on figure 1 it can be seen that the value of Indonesia's cosmetics export tends to increase. This indicates that the performance of Indonesia's cosmetics export continues to improve. The increasing value of export indicates that the spread of 


\section{ANALYSIS OF INTRA-INDUSTRY TRADE IN COSMETIC COMMODITIES BETWEEN INDONESIA AND NINE TRADING PARTNERS IN THE ASIAN REGION IN THE PERIOD OF 2004-2018}

Indonesia's cosmetics market and its product recognition abroad also increase subsequently.

On the other hand, the value of Indonesia's import from 2004-2018 also tends to increase. This indicates that the increase in export of Indonesia's cosmetics was also followed by an increase in foreign cosmetics import. One of the causes of this increasing import is due to high domestic demand for foreign products, especially products from countries such as USA, UK, France, Japan, China, and South Korea. Furthermore, according to EIBN report (2019), the high import of cosmetics can be caused by the behavior of upper-middle-class people who tend to be willing to pay more for products with well-known brands from abroad because it reflects a higher social status.

Based on the data of export and import of cosmetic commodities in the International Trade Center, Indonesia was seen to mutually export and import cosmetic commodities with fellow ASEAN members and other countries in the Asian region, namely Singapore, Malaysia, Thailand, Philippines, China, Hong Kong, India, Japan, and South Korea. The export and import value of Indonesia's cosmetic commodities from these nine countries are quite high, especially when compared to other Asian countries.

Table 1

Export Value of Indonesia's Cosmetics Based on Nine Trading Partners in the Asian Region in the Period of 2014-2018 (thousand US\$)

\begin{tabular}{lrrrrr}
\hline Country & $\mathbf{2 0 1 4}$ & $\mathbf{2 0 1 5}$ & $\mathbf{2 0 1 6}$ & $\mathbf{2 0 1 7}$ & $\mathbf{2 0 1 8}$ \\
\hline Singapor & 116. & 101. & 126. & 154. & 173. \\
e & 311 & 255 & 021 & 298 & 867 \\
Malaysi & 49.1 & 45.6 & 44.3 & 37.7 & 35.0 \\
a & 40 & 96 & 62 & 67 & 18 \\
Thailand & 39.2 & 41.2 & 45.3 & 44.8 & 44.8 \\
Philippi & 16 & 66 & 44 & 54 & 91 \\
nes & 45.4 & 32.2 & 31.0 & 32.9 & 30.0 \\
China & 57 & 49 & 20 & 72 & 72 \\
& 1.91 & 1.68 & 2.23 & 3.56 & 3.13 \\
Hong & 7 & 9 & 9 & 4 & 7 \\
Kong & 15.0 & 11.4 & 7.68 & 4.88 & 4.73 \\
India & 97 & 74 & 7 & 9 & 2 \\
Japan & 5.08 & 4.24 & 4.21 & 5.66 & 7.65 \\
& 5 & 2 & 2 & 2 & 7 \\
South & 8.25 & 3.86 & 7.25 & 6.65 & 8.53 \\
Korea & 3 & 3 & 1 & 4 & 3 \\
\hline
\end{tabular}

Source: International Trade Centre, processed (2019)

Table 1 shows the value of Indonesia's cosmetic exports based on nine of its trading partners in Asia, namely Singapore, Malaysia, Thailand, Philippines, China, 
AFEBI Economic and Finance Review (AEFR)

\section{Volume 5, No 02 (2020)}

Hong Kong, India, Japan, and South Korea. The value of Indonesia's export to the nine countries have fluctuated, however, the value of Indonesia's cosmetic export to Singapore and Thailand tended to increase. As for the past five years, Singapore is a country that has the highest contribution to the value of Indonesia's cosmetic export compared to other countries.

On the other hand, the value of Indonesia's import from these nine countries is fluctuated and tended to increase, especially countries such as China, Hong Kong, India, Japan, and South Korea (see table 2). As for the past five years, the highest value of Indonesia's cosmetic import is from Thailand, although in 2017 and 2018, the value of Indonesia's cosmetic import from Thailand had decreased significantly compared to previous periods.

Table 2

Import Value of Indonesia's Cosmetics Based on Nine Trading Partners in the Asian Region in the Period of 2014-2018 (thousand US\$)

\begin{tabular}{lrrrrr}
\hline Country & $\mathbf{2 0 1 4}$ & $\mathbf{2 0 1 5}$ & $\mathbf{2 0 1 6}$ & $\mathbf{2 0 1}$ & $\mathbf{2 0 1}$ \\
& & & & $\mathbf{7}$ & $\mathbf{8}$ \\
\hline Singapor & 2.205 & 1.611 & 1.332 & 12.9 & 4.94 \\
e & & & & 37 & 8 \\
Malaysia & 13.39 & 11.38 & 11.94 & 8.93 & 14.5 \\
& 4 & 7 & 2 & 0 & 95 \\
Thailand & 161.6 & 151.0 & 139.9 & 72.3 & 76.9 \\
& 70 & 20 & 25 & 07 & 10 \\
Philippin & 794 & 1.132 & 1.784 & 3.84 & 1.50 \\
es & & & & 6 & 5 \\
China & 36.77 & 31.92 & 35.98 & 48.5 & 81.1 \\
& 9 & 8 & 8 & 79 & 80 \\
Hong & 628 & 249 & 966 & 2.11 & 20.5 \\
Kong & & & & 7 & 94 \\
India & 4.919 & 7.237 & 10.88 & 16.2 & 20.5 \\
& & & 1 & 66 & 82 \\
Japan & 23.56 & 27.41 & 28.69 & 32.7 & 35.6 \\
South & 4 & 2 & 8 & 13 & 07 \\
Korea & 4.833 & 4.825 & 7.950 & 13.1 & 34.2 \\
\hline
\end{tabular}

Source: International Trade Centre, processed (2019)

Grimwade (1989) mentioned several factors that can affect the level of intraindustry trade, namely the size of the country as indicated by the size of GDP, the level of income per capita, the difference in the level of income per capita, and distance. The tariff which is one of the trade barriers can also affect the level of intra-industry trade. The higher the average tariff, the lower the level of intra- 


\section{ANALYSIS OF INTRA-INDUSTRY TRADE IN COSMETIC COMMODITIES BETWEEN INDONESIA AND NINE TRADING PARTNERS IN THE ASIAN REGION IN THE PERIOD OF 2004-2018}

industry trade (Caves (1981), Falvey (1981), Davis (1998) in Jaimin and Sangyong (2008)).

Although the trade between Indonesia and each of these trading partners in cosmetic commodities has been seen to have a two-way trade pattern (intraindustry), however, there is still a possibility of a low level of intra-industry trade. This is because some of the trading partners are developed countries, whereas Indonesia is still said to be a developing country. Trade that occurs between countries with different level of development still tends to have a one-way trade pattern. However, it is also possible that there is a high intra-industry trade because most trading partners are developing countries as well. Usually, developing countries have a similar pattern of demand and similar product preference.

Intra-industry trade is becoming more important for every country because it is related to the competitive capability and the competitiveness of industry on an international scale (Bato, 2014). In addition, intra-industry trade is believed to have a positive impact and a better advantage than inter-industry trade. This is because intra-industry trade promotes the increase of economies of scale and encourages innovation. Hence, this study will analyze the level of intra-industry trade in cosmetic commodities between Indonesia and nine trading partners in the Asian region (Singapore, Malaysia, Thailand, Philippines, India, China, Hong Kong, Japan, and South Korea) so that it can be known whether the level of intra-industry trade in cosmetic commodities between Indonesia and its nine trading partners is already high or still low. This study will also see the effect of average country size, average per capita income, difference in per capita income, distance, and average tariff on the level of intra-industry trade between Indonesia and its nine trading partners.

\section{LITERATURE REVIEW \\ International Trade Theory}

In the $17^{\text {th }}$ and $18^{\text {th }}$ centuries, a thought of international trade by mercantilists developed. According to mercantilists, the way for a nation to become rich and powerful, the country must export more than import. The mercantilists strongly believed in the power of government where government power can be used to stimulate or inhibit export and import. Besides, according to mercantilists, a nation would gain an advantage when it sacrifices another nation because nations cannot simultaneously gain an export surplus.

Later on, the theory of absolute advantage was introduced by a classical economist, namely Adam Smith. This theory is very contrary to the assumption of mercantilists, where Adam Smith and other classical economists believed that every nation would get an advantage from free trade and strongly recommend the laissezfaire policy. Every nation would get an advantage when they specialized in the production of a commodity that has an absolute advantage and then exchange it with other commodity from other country that also has an absolute advantage. However, this theory has a weakness in the case where the trade will not occur if 


\section{AFEBI Economic and Finance Review (AEFR)}

\section{Volume 5, No 02 (2020)}

there is one country that does not have an absolute advantage because it is considered to not provide benefits (Salvatore, 2013).

The weaknesses of Adam Smith's theory were later criticized by David Ricardo who later introduced the comparative advantage theory. According to this theory, trade could still occur even though there is one country that has no absolute advantage. Trade can provide benefits when each country specializes in goods where the country has a comparative advantage. Then the country will export goods that have a comparative advantage and import goods that have no comparative advantage. What is meant by the comparative advantage is the ability of a country to produce goods with a smaller opportunity cost where it must sacrifice a few of the goods produced to produce other goods compared to other countries (Mankiw, 2001). David Ricardo's theory also has a weakness where international trade can occur when there is a difference in productivity or difference in efficiency between countries. However, this theory not able to explain the differences in productivity, except the possible differences in climate (Salvatore, 2013). This was later refined by the Hekchsher-Ohlin theory.

The Hecksher-Ohlin theory was introduced by the Swedish economist namely Eli Hecksher and his student Bertil Ohlin. According to the Hecksher-Ohlin theory, the cause of the difference in productivity is due to differences in the proportion of production factors (labor, capital) owned by each country which then causes the difference in the price of goods. Each country will export commodity whose production intensively uses relatively abundant and cheap factors in their country and will import commodity whose production intensively uses relatively rare and expensive factors in their country (Salvatore, 2013). However, in reality, the pattern of trade that occurred today turns out to be more characterized by trade between countries which generally have the same factor endowments as well as characterized by the pattern of exchange of similar goods (Krugman, 1981). Thus, the conventional theory is considered unreliable in explaining the phenomenon of international trade with this pattern.

\section{Intra-Industry Trade (IIT)}

Intra-industry trade is a new trade theory that emerged as the answer to the new reality in current pattern of international trade which cannot be explained by the conventional theory (Bato, 2014). Intra-industry trade is a trade of products from the same classification or industry. This pattern of trade was mostly practiced among developed countries in the 1980s and later in the 1990s, similar thing also happened in developing countries with high growth rates such as ASEAN countries and new industrial countries in the East Asia (Suidarma, 2019). Unlike interindustry trade which is based on comparative advantage, intra-industry trade is based more on economies of scale (increasing return to scale). In this case, the international competition encourages each firm in countries to specialize in producing only one or at most a few varieties and styles of the same product rather than producing many different varieties and styles. This is crucial in keeping cost per unit low. The goods will later be produced on a higher amount and with better quality as a result of the specialization. The country will later import other varieties 


\section{ANALYSIS OF INTRA-INDUSTRY TRADE IN COSMETIC COMMODITIES BETWEEN INDONESIA AND NINE TRADING PARTNERS IN THE ASIAN REGION IN THE PERIOD OF 2004-2018}

and styles from other countries. Intra-industry trade benefits consumers because it provides a wider choice of products and the price of these products will be cheaper as a result of economies of scale (Salvatore, 2013).

Grimwade (1989) in his book entitled "International Trade: New Patterns of Trade, Production and Investment”, as well as Balassa and Bauwens (1987), mentions several factors that can affect the level of intra-industry trade which are reviewed based on country characteristics, namely the level of income per capita, the degree of income per capita equality or the difference of per capita income, the size of the country, size differences, the degree of integration exiting between countries, differences in the level of development between countries, distance, et cetera. While the factors that can affect the level of intra-industry trade which are reviews based on industry characteristics are economies of scale, product differentiation, foreign investment, tariff, et cetera.

\section{METHODOLOGY}

The research unit in this study is cosmetic commodities based on the 4-digit HS (Harmonized System) classification namely HS code 3303 (perfumes and toilet waters), HS code 3304 (beauty or makeup preparations and preparations for the care of the skin, including sunscreen or suntan preparations (excluding medicaments); manicure or pedicure preparations), HS code 3305 (preparation for use on the hair), HS code 3306 (preparation for oral or dental hygiene, incl. denture fixative pastes and powders) and HS code 3307 (shaving preparations, incl. pre-shave and aftershave products, personal deodorants, bath and shower preparations, depilatories and other perfumery). While the research objects in this study are countries in the Asian region, namely Indonesia, Singapore, Malaysia, Thailand, Philippines, India, China, Hong Kong, Japan, and South Korea. The type of data used in this study is secondary data which was obtained from United Nations Comtrade Database (UN Comtrade), International Trade Centre, World Bank, Haveman, WITS (World Integrated Trade Solution), Central Bureau of Statistics (BPS), Ministry of Trade, Ministry of Industry, et cetera.

\section{IIT Index Analysis (Grubel-Llyod Index)}

In measuring the level of intra-industry trade, this study uses an index called Grubel-Llyod Index. The Grubel-Llyod Index was developed by Grubel and Llyod in 1967 and became the most commonly used calculation in determining the level of intra-industry trade. The Grubel-Llyod Index is formulates as follows:

$$
\mathrm{IIT}_{\mathrm{ijkt}}=\left[1-\frac{\sum\left|\mathrm{X}_{\mathrm{ijkt}}-\mathrm{M}_{\mathrm{ikjt}}\right|}{\sum\left(\mathrm{X}_{\mathrm{ijkt}}+\mathrm{M}_{\mathrm{ijkt}}\right)}\right] \times 100
$$

Where:

$$
\begin{array}{ll}
\text { IIT } & =\text { Intra-industry Trade } \\
X & =\text { Export (US\$) } \\
\mathrm{M} & =\text { Import (US\$) } \\
\mathrm{i} & =\text { Reporter country }
\end{array}
$$




\section{AFEBI Economic and Finance Review (AEFR)}

\section{Volume 5, No 02 (2020)}

$\mathrm{j} \quad=$ Partner country

$\mathrm{k} \quad=$ Type of cosmetic product or commodity based on HS 4-digit classification

$\mathrm{t}=$ year

If trade transaction is balanced or two-way (two-way trade) then the index is worth 100 percent, but if trade transaction between countries is one-way trade then the index is worth 0. Based on the classification used by OECD (2002) if the IIT index value above 50 then a country is classified as having a high level of intraindustry trade, however, if the IIT index is low (below 50), then the country has a low level of intra-industry trade.

\section{Panel Data Analysis}

To analyze the determinants of intra-industry trade of cosmetic commodities between Indonesia and nine trading partners in the Asian region, this study uses the static panel data method. Panel data is a combination of time-series data and individual or cross-section data (Baltagi in Gujarati, 2011). This study uses timeseries data for fifteen years, namely data from 2004 to 2018 and cross-section data of nine trading partners which produced 135 observations.

There are several models in the panel data analysis, namely pooled least square or common effect model, fixed effect model, and random effect model. However, this research emphasized the fixed effect model and random effect model because the pooled least square model is considered to ignore the trait of cross-section and time-series. The Hausman test is used to determine the best regression model between fixed effect model (FEM) or random effect model (REM).

The variables used in this study are the level of intra-industry trade of cosmetic commodities (IIT) as the dependent variable and the average size of the two countries (ASIZE), the average income per capita of two countries (APC), the difference in income per capita of two countries (DPC), the distance between two countries (DIST) and the average tariff of cosmetics import imposed by each country (ATRF) as the independent variable. The research model to be estimated is as follows:

$$
\begin{aligned}
\mathrm{IIT}_{\mathrm{ijt}} & =\beta_{0}+\beta_{1} \ln \left(\mathrm{ASIZE}_{\mathrm{ijt}}\right)+\beta_{2} \ln \left(\mathrm{APC}_{\mathrm{ijt}}\right)+\beta_{3} \ln \left(\mathrm{DPC}_{\mathrm{ijt}}\right) \\
& +\beta_{4} \ln \left(\mathrm{DIST}_{\mathrm{ijt}}\right)+\beta_{5}\left(\mathrm{ATRF}_{\mathrm{ijt}}\right)+\varepsilon_{\mathrm{ijt}}
\end{aligned}
$$

Where:

IIT $_{\mathrm{ijt}} \quad=$ The level of intra-industry trade between country $\mathrm{i}$ and $\mathrm{j}$

ASIZE $_{i j t} \quad=$ The average size of country $i$ and $j$ in the year $t$ (US\$) which is

calculated using the following formula:

$\mathrm{ASIZE}_{\mathrm{ij}}=\frac{\mathrm{GDP}_{\mathrm{i}}+\mathrm{GDP}_{\mathrm{j}}}{2}$

$\mathrm{APC}_{\mathrm{ijt}} \quad=$ The average income per capita of country $\mathrm{i}$ and $\mathrm{j}$ in the year $\mathrm{t}$ (US\$)

which is calculated using the following formula:

$\mathrm{APC}_{\mathrm{ij}}=\frac{\mathrm{GDPC}_{\mathrm{i}}+\mathrm{GDPC}_{\mathrm{j}}}{2}$

$\mathrm{DPC}_{\mathrm{ijt}} \quad=$ The difference in income per capita of country $\mathrm{i}$ and $\mathrm{j}$ in the year $\mathrm{t}$ 


\section{ANALYSIS OF INTRA-INDUSTRY TRADE IN COSMETIC COMMODITIES BETWEEN INDONESIA AND NINE TRADING PARTNERS IN THE ASIAN

(US\$) which is calculated using the following formula:

$$
\begin{aligned}
& \mathrm{DPC}_{\mathrm{ij}}=1+\frac{[\mathrm{vlnv}+(1-\mathrm{v}) \ln (1-\mathrm{v})]}{\ln 2} \\
& \mathrm{v}=\frac{\mathrm{GDPC}_{\mathrm{i}}}{\mathrm{GDPC}_{\mathrm{i}}+\mathrm{GDPC}_{\mathrm{j}}}
\end{aligned}
$$

DIST $_{\mathrm{ijt}} \quad=$ The distance between country $\mathrm{i}$ and $\mathrm{j}$ in the year $\mathrm{t}(\mathrm{km})$

Geographical distance is constant overtime, so the distance used in this study is the weighted distance between country $i$ and $j$ or what is often referred to as economic distance. Refer to Li et al. (2008), Turkcan and Ates (2010), Widyastutik (2013), and Inayah et al., 2016, distance is calculated using the following formula:

$$
\operatorname{DIST}_{\mathrm{ij}}=\frac{\mathrm{D}_{\mathrm{ij}} * \mathrm{GDP}_{\mathrm{j}}}{\text { total GDP }}
$$

Where $D_{i j}$ is the geographical distance between country $i$ and $j$

$\mathrm{ATRF}_{\mathrm{ijt}} \quad=$ The average tariff applied by country $\mathrm{i}$ and country $\mathrm{j}$ on imported cosmetics from country $j$ and country $i$ in the year $t(\%)$

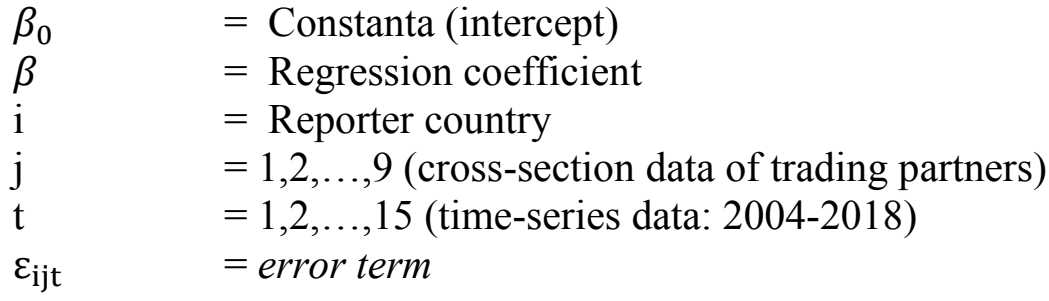

\section{RESULT AND DISCUSSION}

Based on the Grubel-Llyod Index calculation, the average level of intraindustry trade in cosmetic commodities between Indonesia and each of its trading partners during the period of 2004-2018 are shown in the Table 3.

Table 3

Average Level of IIT in Cosmetic Commodities between Indonesia and Each of Its Trading Partners during the Period of 2004-2018 (\%)

\begin{tabular}{lc}
\hline \multicolumn{1}{c}{ Country } & $\begin{array}{c}\text { Average Level of IIT } \\
(\%)\end{array}$ \\
\hline Indonesia- & 21.40 \\
Singapore & 42.86 \\
Indonesia-Malaysia & 18.73 \\
Indonesia-Thailand & 11.80 \\
Indonesia- & \\
Philippines & 58.68 \\
Indonesia-India & 24.40 \\
Indonesia-China & \\
\hline
\end{tabular}


AFEBI Economic and Finance Review (AEFR)

\section{Volume 5, No 02 (2020)}

\begin{tabular}{lc}
\hline Indonesia-Hong & 12.62 \\
Kong & 35.50 \\
Indonesia-Japan & 46.00 \\
Indonesia-South & \\
Korea & \\
\hline
\end{tabular}

Source: UN Comtrade, processed (2020)

Based on Table 3, it can be seen that the level of intra-industry trade between Indonesia and each of its trading partners are still low, where the average value of the IIT index is still below 50 percent (except India). Based on the classification used by OECD (2002), if the IIT index value is below 50 percent then intra-industry trade is low. The low average value of the IIT index is due to a quite big difference on the export and import value between Indonesia and the trading partners.

By looking at the data of Indonesia's cosmetic commodities trade flow, it turns out that Indonesia is still more dominant in exporting cosmetic commodities to Philippines, Hong Kong, and Singapore compared to importing from these countries, but still more dominant in importing from Thailand, China, Japan, and South Korea compared to exporting to these countries. The greater value of Indonesia's import from the four trading partners could be caused by the mismatched of Indonesia's cosmetic product with the partner countries' preference, where the partner countries are not so favored to Indonesia's products. On the contrary, the cosmetic products by the four countries are highly favored by Indonesians. The high import of Indonesia from South Korea can be caused by the "Hallyu Wave" or "Korean Wave" phenomenon which is a phenomenon where people are introduced to South Korean culture through music, fashion, drama and so on. Through these media, people are become interested too in beauty trends of South Korean-style, so this result in people from around the world including Indonesia to become very fond of South Korea's beauty products in order to keep up with this trend. Then, the deficit trade balance in the trade of cosmetic commodities between Indonesia and Thailand could also be caused by the tariff imposed by Thailand on Indonesia's cosmetic products that are still quite high, subsequently, Indonesia's cosmetic products will become expensive in Thailand and reduce their competitiveness which then implicates to Indonesia's low export.

On the other hand, only the level of intra-industry trade between Indonesia and India can be said to be high, where the average value of the IIT index is already above 50 percent. The high level of intra-industry trade between Indonesia and India can be caused by the influence of similar taste, where Indian people prefer and also produce cosmetics made from natural ingredients (ITPC Chennai, 2013), similar case with Indonesian people who tend to favor natural products.

Moreover, each year, the level of intra-industry trade in cosmetic commodities between Indonesia and each of its trading partners still tend to fluctuate, which sometimes experience an increasing or decreasing (shown in Figure 2). This is because the export and import values between Indonesia and the nine trading partners tend to be unstable and continue to fluctuate. The fluctuation in the value of export and import can be caused by factors such as changes in exchange rate, 
ANALYSIS OF INTRA-INDUSTRY TRADE IN COSMETIC COMMODITIES

BETWEEN INDONESIA AND NINE TRADING PARTNERS IN THE ASIAN

REGION IN THE PERIOD OF 2004-2018

changes in the level of GDP and GDP per capita, inflation, changes in the behavior or pattern of public demand, et cetera.

\section{Figure 2}

The Development of The Level of IIT in Cosmetic Commodities between Indonesia and Nine Trading Partners in the Asian Region in the Period of 2004-2018 (\%)

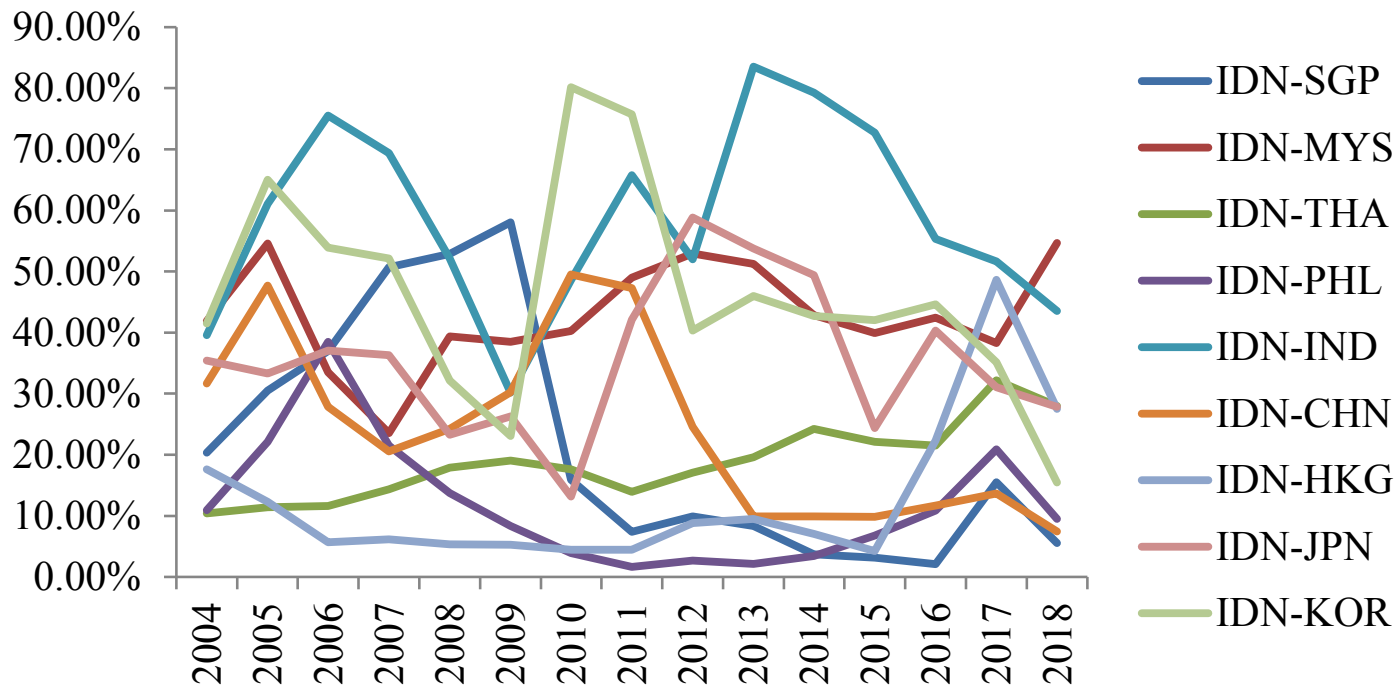

Information: IDN (Indonesia); SGP (Singapore); MYS (Malaysia); PHL (Philippines);

(South

IND (India); CHN (China); HKG (Hong Kong); JPG (Japan); KOR

Korea).

Source: UN Comtrade, processed (2020)

As for based on the product or commodity type, for 15 years (2004-2018), there was a fairly high two-way trade on HS 3304 and 3307 products between Indonesia and most of its trading partners, where the average value of IIT index for both products tend to be the greatest (can be seen in Table 4)

Table 4

Average Level of IIT in Each Cosmetic Commodity Type between Indonesia and Nine Trading Partners in the Asian Region during the Period of 2004$2018(\%)$

\begin{tabular}{cccccc}
\hline Country & HS & HS & HS & HS & HS \\
& $\mathbf{3 3 0 3}$ & $\mathbf{3 3 0 4}$ & $\mathbf{3 3 0 5}$ & $\mathbf{3 3 0 6}$ & $\mathbf{3 3 0 7}$ \\
\hline Indonesia- & 26.2 & 28.3 & 12.0 & 14.2 & 49.2 \\
Singapore & 7 & 0 & 5 & 0 & 5 \\
\hline
\end{tabular}


AFEBI Economic and Finance Review (AEFR)

Volume 5, No 02 (2020)

\begin{tabular}{lccccc}
\hline Indonesia- & 8.45 & 59.1 & 17.7 & 25.6 & 72.9 \\
Malaysia & & 4 & 5 & 6 & 1 \\
Indonesia- & 17.7 & 69.8 & 17.2 & 0.92 & 45.2 \\
Thailand & 8 & 5 & 2 & & 5 \\
Indonesia- & 12.0 & 32.1 & 1.80 & 0.48 & 23.3 \\
Philippine & 7 & 3 & & & 5 \\
s & & & & & \\
Indonesia- & 12.1 & 70.7 & 63.5 & 20.6 & 44.5 \\
India & 4 & 1 & 9 & 4 & 4 \\
Indonesia- & 25.6 & 6.55 & 39.8 & 49.2 & 30.0 \\
China & 2 & & 3 & 8 & 9 \\
Indonesia- & 19.2 & 11.3 & 9.17 & 9.28 & 46.2 \\
Hong & 7 & 2 & & & 5 \\
Kong & & & & & \\
Indonesia- & 20.1 & 50.5 & 41.5 & 11.5 & 44.3 \\
Japan & 8 & 9 & 1 & 3 & 1 \\
Indonesia- & 17.7 & 48.5 & 38.1 & 10.1 & 42.4 \\
South & 1 & 5 & 8 & 0 & 2 \\
Korea & & & & & \\
\hline
\end{tabular}

Source: UN Comtrade, processed (2020)

Then, in analyzing the determinants of intra-industry trade in cosmetic commodities between Indonesia and its nine trading partners, the panel data method was used. Based on the result of Hausman test and the results of classical assumptions test or econometrics criteria (multicollinearity test, heteroscedasticity test, autocorrelation test, and normality test), the best regression model is fixed effect model using Generalized Least Square (EGLS) method with weighting Cross-Section SUR. The results of panel data regression estimation can be seen in Table 5.

Table 5

Panel Data Regression Estimation Result

Dependent variable: IIT

\begin{tabular}{lccl}
\hline Variable & Coefficient & $\begin{array}{c}\text { t- } \\
\text { statistic }\end{array}$ & Explanation \\
\hline LN_ASIZE & 0,381044 & 3,194877 & Sig at $\alpha=5 \%$ \\
LN_APC & 0,536402 & 2,982379 & Sig at $\alpha=5 \%$ \\
LN_DPC & $-0,011341$ & - & Sig at $\alpha=5 \%$ \\
LN_DIST & $-0,832257$ & 2,023017 & Sig at $\alpha=5 \%$ \\
ATRF & 0,573386 & $-8,851652$ & \\
R $^{2}$ & 0,859473 & Sig at $\alpha=5 \%$ \\
F-statistic & 56,92660 & Sig at $\alpha=5 \%$ \\
\hline
\end{tabular}


ANALYSIS OF INTRA-INDUSTRY TRADE IN COSMETIC COMMODITIES BETWEEN INDONESIA AND NINE TRADING PARTNERS IN THE ASIAN

REGION IN THE PERIOD OF 2004-2018

\begin{tabular}{ll}
\hline $\begin{array}{l}\text { Dw } \\
\text { Statistic }\end{array}$ & 1,801532 \\
\hline \multicolumn{2}{c}{ Source: Estimation Result with Eviews 10, processed (2020) }
\end{tabular}

In Table 5 it can be seen that the coefficient of determination $\left(R^{2}\right)$ is 0,8594 percent, meaning that 85,94 percent of the level of intra-industry trade between Indonesia and each of its trading partners can be explained by the independent variables in the model. While the rest which is 14,06 percent is explained by other variables outside the model. The coefficient of determination shows that the research model is good to be used.

Then in Table 5, it can also be seen that the level of F-statistic is 56,92660, so F-statistic $(56,92660)>$ F-table $(2,28)$, then it can be concluded that the independent variables simultaneously have a significant effect on the dependent variable (the level of intra-industry trade).

The Effect of Average Country Size (ASIZE) on the Level of Intra-Industry Trade in Cosmetic Commodities

Based on the estimation results shown in Table 5, the average country size variable (ASIZE) has a positive and significant effect on the level of intra-industry trade (IIT). As the average country size increase by 1 percent, the level of intraindustry trade will increase by 0,3810 percent. This is very likely to occur because a large average country size (GDP) indicates a large market in each country where there is a high demand for products and the possibility of the variety of differentiated goods produced under conditions of scale economies (increasing return to scale) is also great. So, the greater the average country size (GDP), the higher the level of intra-industry trade (Lancaster, 1980; Balassa and Bauwens, 1987; Grimwade, 1989; Phan and Jeong, 2014).

This result is supported by research conducted by Phan and Jeong (2014) related to intra-industry trade in manufacturing sector between Korea and ASEAN, the research by Turkcan and Ates (2010) related to intra-industry in auto-industry between the US and 37 trading partners, research by Jing et al., (2010) related to intra-industry trade in agricultural products in China and research by Setyawati (2018) related to intra-industry trade in all sectors between Indonesia and trading partners in the Asian region which also found that the average country size (GDP) has a positive effect on intra-industry trade.

\section{The Effect of Average Per Capita Income (APC) on the level of Intra-Industry} Trade in Cosmetic Commodities

The estimation results in Table 5 show that the average per capita income (APC) variable has a positive and significant effect on the level of intra-industry trade (IIT). As the average per capita income increase by 1 percent, the level of intra-industry trade will increase by 0,5364 percent.

There is a positive correlation between average income per capita with the level of intra-industry trade and the average per capita income represents the demand for differentiated products (Balassa and Bauwens, 1987; Linder, 1961), thus the higher 


\section{AFEBI Economic and Finance Review (AEFR)}

\section{Volume 5, No 02 (2020)}

the average per capita income of the two countries, the greater the demand for variety in both countries. The demand for variety will encourage an increase in production that focuses on product differentiation, so that intra-industry trade will increase and inter-industry trade will decrease (Grimwade, 1989).

This result is supported by previous research that conducted by Marius-Răzvan and Camelia (2015) related to intra-industry trade in the motor vehicle parts and accessories sector between Romania and 13 EU countries and research by Bahari (2015) related to intra-industry trade in agricultural sector between Indonesia and its nine trading partner countries which also found that average per capita income has a positive effect on the level of intra-industry trade.

\section{The Effect of Difference in Per Capita Income (DPC) on the Level of Intra- Industry Trade in Cosmetic Commodities}

Based on the estimation results shown in Table 5, the variable difference in per capita income (DPC) has a negative and significant effect on intra-industry trade. As the difference per capita increases by 1 percent, the level of intra-industry trade will decrease by 0,0113 percent.

According to Grimwade (1989), the level of per capita income has a strong influence on the pattern of demand. Oftentimes a product that produced by a country to meet local taste also tends to be in demand by other countries that have a similar level of per capita income. Therefore, the difference in per capita income has a negative effect on the level of intra-industry trade where the greater the difference in per capita income of the two countries, the more dissimilar the pattern of demand (the more different the taste) and the lower the level of intra-industry trade.

In this case, a country with a high level of per capita income reflects the high standard of living, so the demand for high-end cosmetic products which have a high quality and luxury will be high. As a result, producers in rich countries will be encouraged to produce cosmetic products by their country's standards and the country will get benefit if the country exports its products to other rich countries. However, such products would not obtain a large market in countries with a level of income per capita that still tends to be low, because they tend to have no need such products, including Indonesia. Although high-end cosmetic products are still able to be bought by people in countries with low income per capita (especially people with middle to upper income), but usually people will tend to prefer more affordable products but still have good quality and suitable for their skin, face, hair, and so on. Because there are so many good quality products that are not inferior to high-end products and the price of the products are much cheaper than the high-end products, both cosmetic products which produced by domestic or imported cosmetic products from other countries.

This result is supported by research conducted by Jing et al., (2010) related to intra-industry trade in agricultural products between China and its trading partners, and research by Bahari (2015) related to intra-industry trade in agricultural sector between Indonesia and its nine trading partner countries which also found that the

difference in per capita income has a negative effect on the level of intra-industry trade. 


\section{ANALYSIS OF INTRA-INDUSTRY TRADE IN COSMETIC COMMODITIES BETWEEN INDONESIA AND NINE TRADING PARTNERS IN THE ASIAN REGION IN THE PERIOD OF 2004-2018}

\section{The Effect of Distance (DIST) on the Level of Intra-Industry Trade in Cosmetic Commodities}

The estimation results in Table 5 show that the distance variable (DIST) has a negative and significant effect on the level of intra-industry trade. As the distance increase by 1 percent, the level of intra-industry trade will decrease by 0,08322 percent.

According to Grimwade (1989), the greater the distance between countries, the lower the level of intra-industry trade. Distance shows the transportation and transaction costs faced by trading countries. High transportation or transaction costs can have an impact on declining international trade (export and import). This is what later led to the decline in the level of intra-industry trade, So it can be said that the greater the distance, the greater the transportation costs and the lower the level of intra-industry trade.

This result is supported by research conducted by Turkcan and Ates (2010) related to intra-industry trade in auto-industry between the US and 37 trading partners, and research by Pitaloka (2019) related to intra-industry trade in the machinery and transportation equipment sector which found that distance has a negative effect on the level of intra-industry trade.

\section{The Effect of Average Tariff (ATRF) on the Level of Intra-Industry Trade in Cosmetic Commodities}

Based on the estimation results shown in Table 5, the average tariff has a positive and significant effect on the level of intra-industry trade. As the average tariff increase by 1 percent, the level of intra-industry trade will increase by 0,5733 percent.

This result is different from the previous research conducted by Jaimin and Sangyong (2008) where the average tariff has a negative effect on the level of intraindustry trade. In the case of cosmetic commodities trade between Indonesia and its trading partners such as with Singapore, Philippines, and Hong Kong, the low average tariff apparently have not been capable to increase the level of intraindustry trade where the level of intra-industry trade tend to be low, even though their average tariff are very low every year ( 0 percent -5 percent). Conversely, the average tariff of Indonesia-India still tends to be higher than Philippines, Singapore, and Hong Kong, but their level of intra-industry trade tends to be large every year, so this could be the cause of the different result.

Moreover, the tariff applied by Indonesia on imported cosmetic products from trading partners and the tariff imposed by trading partners on imported cosmetic products from Indonesia are not always the same every year and basically the demand or behavior of society is always changing too. So it is probable that at certain times high tariff can increase the intra-industry trade in cosmetic commodities.

\section{CONCLUSION}




\section{AFEBI Economic and Finance Review (AEFR)}

\section{Volume 5, No 02 (2020)}

The Grubel-Llyod Index calculation results show that the level of intra-industry trade in cosmetic commodities between Indonesia and each of its trading partners (except India) are still low, where the average value of the IIT index are still below 50 percent. In this case, Indonesia is still more dominant in exporting cosmetic commodities to Philippines, Hong Kong, and Singapore compared to importing from these countries, but still more dominant in importing from Thailand, China, Japan, and South Korea compared to exporting to these countries. Consequently, the government and cosmetic industry or cosmetic companies needs to create various efforts to maintain or increase the export of Indonesia's cosmetic commodities. This can be done by developing market intelligence and increasing promotional strategies which appropriate and efficient, such as participating in exhibitions or foreign trade shows that focus on cosmetic products, holding the socialization in the partner countries and other countries, and increasing the promotion through social media, print media or television. Cosmetic companies can also cooperate with beauty vloggers or beauty influencers in promoting Indonesia's cosmetic products so that in the future Indonesia's cosmetic products will be even more known and desirable by foreign countries. Moreover, government also needs to simplify the investment procedure as well as provides incentive for investment so that it will encourage the enhancement of investment which can help the cosmetic industry to increase the productivity and able to increase the export.

Based on the estimation results, the average country size, average per capita income, and average tariff have a positive and significant effect on the level of intraindustry trade in cosmetic commodities. The positive effect of the average country size on the level of intra-industry trade shows that the economies of scale and product differentiation are very important in encouraging intra-industry trade, so the cosmetics industry needs to increase the use of technology, optimize the use of inputs, as well as increasing innovation and creativity while still paying attention to safety and health matter so that later the number of cosmetic products that produced will be greater, varied, safe to use and suitable for every society (does not trigger allergies, irritants, or dangerous for health). Then, it is also found that the difference in per capita income has a negative and significant effect on the level of intraindustry trade in cosmetic commodities. The difference in per capita income itself reflects the difference in taste between countries. Therefore, the business actors need to conduct market research continuously and intensively or carry out an R\&D (Research and Development) programs to obtain information about cosmetic products that are currently popular and favored by other countries and domestic. Other than that, through the R\&D program, it is also possible to find out what kind of product that is suitable and safe to use for every society (both foreign and domestic society), so that later the business actors can produce or develop products according to their preference. Distance also has a negative and significant effect on the level of intra-industry trade. Hence, the government and other parties involved need to create various efforts to minimize the transportation cost, one thing that can be done is to provide good transportation facilities for the smooth process of international trade. 


\section{ANALYSIS OF INTRA-INDUSTRY TRADE IN COSMETIC COMMODITIES BETWEEN INDONESIA AND NINE TRADING PARTNERS IN THE ASIAN REGION IN THE PERIOD OF 2004-2018}

\section{REFERENCES}

Bahari, F. (2015). Analisis Perdagangan Intra-Industri di Sektor Pertanian. Skripsi. Semarang: Universitas Diponegoro.

Balassa, B., \& Bauwens, L. (1987). Intra-Industry Specialisation in a Multi-Country and Multi-Industry Framework. The Economic Journal, 97(388), 923-939.

Basri, F. H. (1992). Perkembangan Terbaru Teori Perdagangan Internasional. Ekonomi Dan Keuangan Indonesia, 40(3), 219-246. https://www.lpem.org/repec/lpe/efijn1/199211.pdf

Bato, A. R. (2014). Perdagangan Intra Industri Indonesia Dengan Beberapa Negara Partner Dagang. EcceS (Economics, Social, and Development Studies), 1(1), 28 40. http://journal.uin-alauddin.ac.id/index.php/ecc/article/view/1181

Caves, R. E. (1981). Intra-Industry Trade and Market Structure in the Industrial Countries. Oxford Economic Papers, 33(2), 203-223. https://doi.org/10.1093/oxfordjournals.oep.a041505

Davis, D. R. (1998). The Home Market, Trade, and Industrial Structure. American Economic Review, 88(5), 1264-1276. https://doi.org/10.2139/ssrn.943493 EIBN. (2019). EIBN Sector Reports: Cosmetics. Indonesian French Chamber of Commerce and Industry (IFCCI). https://indonesien.ahk.de/fileadmin/AHK_Indonesien/Publication/PDF_Publicatio n/EIBN/2019_EIBN_New_Report_-_Sector_Cosmetics.pdf

Falvey, R. E. (1981). Commercial Policy and Intra-Industry Trade. Journal of International Economics, 11(4), 495-511.

Grimwade, N. (1989). International Trade: New Patterns of Trade, Production and Investment. London and New York: Routledge.

Gujarati, D. N. (2011). Econometrics By Example. London:Palgrave Macmillan. Halwani, H. (2002). Ekonomi Internasional dan Globalisasi Ekonomi. Ghalia Indonesia, Jakarta.

Inayah, I., Oktaviani, R., \& Daryanto, H. K. (2016). The Analysis of Export Determinant of Indonesian Pepper in the International Market. International Journal of Science and Research (IJSR), 5(11), 1856-1860. 


\section{AFEBI Economic and Finance Review (AEFR)}

\section{Volume 5, No 02 (2020)}

https://doi.org/10.21275/ART20163261

International Trade Centre (ITC). Trade Map: Trade Statistics for International Business Development. https://trademap.org/ (accessed on November $5^{\text {th }} 2019$ ).

ITPC Chennai. (2013). Potensi Pasar Kosmetik di India.

Jaimin, L., \& Sangyong, H. (2008). Intra-Industry Trade and Tariff Rates of Korea and China. China Economic Review, 19(4), 697-703. https://doi.org/10.1016/j.chieco.2008.08.003

Jing, W., Leitão, N. C., \& Faustino, H. (2010). Intra-Industry Trade in Agricultural Products: The Case of China. School of Economics and Management Technical University of Lisbon.

Kementerian Perindustrian (KEMENPERIN). (2018). Kian Kinclong, Industri Kosmetik Nasional Tumbuh 20 Persen. https://kemenperin.go.id/artikel/18954/Kian-Kinclong,-Industri-KosmetikNasional-Tumbuh-20-Persen

Krugman, P. R. (1981). Intra-Industry Specialization and the Gains from Trade. Journal of Political Economy, 89(5).

Lancaster, K. (1980). Intra-Industry Trade under Perfect Monopolistic Competition. Journal of International Economics, 10(2), 151-175. https://doi.org/10.1016/0022-1996(80)90052-5

Li, K., Song, L., \& Zhao, X. (2008). Component Trade and China's Global Economic Integration. Component Trade and China's Global Economic Integration.

Linder, S. B. (1961). An Essay on Trade and Transformation. New York: John Wiley \& Son.

Mankiw, N. G. (2001). Principles of Microeconomics (2nd ed.). Harcourt College Publishers/Harcourt, Inc., Ft. Worth, TX, Philadelphia, PA, et al.

Marius-Răzvan, S., \& Camelia, S. (2015). Analysis of the Intra-Industry Trade for the Motor Vehicle Parts and Accessories Sector from Romania. Procedia Economics and Finance, 22(15), 343-352. https://doi.org/10.1016/s2212-5671(15)00301-9

OECD. (2002). Intra-Industry and Intra-Firm Trade and the Internationalisation of Production. OECD Economic Outlook, 2002(1), 159-170. 


\section{ANALYSIS OF INTRA-INDUSTRY TRADE IN COSMETIC COMMODITIES BETWEEN INDONESIA AND NINE TRADING PARTNERS IN THE ASIAN REGION IN THE PERIOD OF 2004-2018}

https://www.oecd.org/economy/outlook/2752923.pdf

Phan, H. T., \& Jeong, Y. J. (2014). An Empirical Analysis of Intra Industry Trade in Manufactures between Korea and ASEAN. Journal of Economic Studies, 41(6), 833-848. https://doi.org/10.1108/JES-01-2013-0006

Pitaloka, G. E. D. (2019). Analisis Pola Perdagangan Intra-Industri (Studi Kasus SITC Kode 7 Sektor Mesin dan Alat Pengangkutan). Skripsi. Semarang: Universitas Diponegoro.

Ramli, N. S. (2015). Immigrant Entrepreneurs on the World's Successful Global Brands in the Cosmetic Industry. Procedia - Social and Behavioral Sciences, 195, 113-122. https://doi.org/10.1016/j.sbspro.2015.06.417

Salvatore, D. (2013). International Economics (11th ed.). John Wiley \& Sons, Inc. Setyawati, E. (2018). Analisis Faktor-Faktor Pengaruh Perdagangan Intra Industri (Intra Industry Trade) Indonesia Dengan Beberapa Mitra Dagang di Kawasan Asia Tahun 2001 - 2017. Skripsi. Yogyakarta: Universitas Negeri Yogyakarta.

Suidarma, I. M. (2019). Dinamika Perdagangan Intra-Industri Sektor Pertanian: Sebuah Kajian Empiris dan Tinjauan Kebijakan. Jember: CV. Pustaka Abadi.

Turkcan, K., \& Ates, A. (2010). Structure and Determinants of Intra-Industry Trade in the U.S. Auto-Industry. Journal of International and Global Economic Studies, 2(2), 15-46.

UN Comtrade. United Nation Comtrade Data Base. https://comtrade.un.org/data/ (accessed on November $5^{\text {th }} 2019$ ).

Widyastutik, A. A. (2013). Pengaruh Variabel Ekonomi dan Non Ekonomi terhadap Impor Indonesia dari ASEAN+6 melalui Moda Transportasi Laut. Buletin Ilmiah Litbang Perdagangan, 7(2), 231-247. 